\title{
Blame it on austerity? Examining the impetus behind London's changing green space governance
}

\author{
Meredith Whitten* \\ London School of Economics and Political Science
}

\begin{abstract}
Urban green spaces play a critical role in the economic, environmental and social sustainability of cities, including London, where 47 per cent of the city is considered green. Yet, a dedicated, sustainable stream of funding for green space does not exist. Cyclical funding and underfunding over the past several decades demonstrate the vulnerability of these non-statutory spaces to changing budgets and government policies. Recent austerity measures are blamed for a decline in green spaces. However, this overlooks urban socioeconomic processes already in motion, particularly relating to a growing and aging population. To counter green space cuts, local authorities are turning to local community organisations - namely, friends groups - to take on green space management. Yet, while these local organisations can fill a gap left by councils, they are not a panacea, and challenges remain for ensuring the long-term, strategic viability of London's urban green spaces.
\end{abstract}

Keywords: Urban green space, environmental governance, London, austerity, friends groups.

\section{Introduction}

The delivery and management of publicly accessible urban green space is a common feature in cities across the world. Local governments provide these spaces for an extensive list of reasons, as urban green spaces contribute to environmental, economic and social sustainability (Chiesura, 2004). Benefits of green space include: opportunities for physical activity (Hillsdon et al., 2006); cooling of increased urban temperatures (Gill et al., 2007); air and water filtration (Heidt and Neef, 2008); flood control and prevention (Zhang et al., 2012); urban agriculture and community gardening (De Bon et al., 2009); biodiversity and habitat protection (Niemelä, 1999); improved physical health and mental well-being (Tzoulas et al., 2007); social interaction and integration (Swanwick, Dunnett and Woolley, 2003); tourism and city marketing (Choumert and Salanié, 2008); increased property values and tax revenue (Choumert and Salanié, 2008; Crompton, 2001); economic competitiveness (Panduro and Veie, 2013); reduced crime and antisocial behaviour (Woolley, 2003); cultural heritage preservation (Urban Parks Forum, 2001); education and child development (Taylor, 1998); and quality of life (Bullock, 2008). 
Yet, these spaces are being asked to perform an increasing array of services for growing and changing populations, while at the same time experiencing substantial cuts to their funding, staffing and other resources. As a result, urban green spaces no longer are the sole responsibility of local authorities, but are now the remit of an evolving partnership among local governments, private developers, charities and community organisations. Key among this partnership is user groups, frequently referred to as friends groups.

This research examines the impetus behind the changing governance of urban green space in London, focusing on the role of friends groups. This paper argues that narrowly attributing the pressure on urban green space to recent cuts in local authorities' budgets ignores structural changes in population and socio-demographics affecting local authorities' ability to manage and maintain London's green spaces. The door for change in green space governance already was opened by increasing populations, socio-demographic changes and growing demands on other local services; austerity merely accelerated this changing governance. Further, this paper argues that, while a shift in green space governance presents opportunities to protect these public spaces from decline and loss, it also presents challenges for the long-term and strategic viability of a London-wide system of urban green spaces (Fors et al., 2015).

The first section of the paper reviews key literature regarding austerity in Britain, including the impact cuts have had on local authorities and the services they provide. In particular, the effect of cuts on discretionary services - how green space is categorised - is examined. This is followed by analysis of literature regarding previous periods of austerity, as well as the concepts of Big Society and localism promoted by Britain's central government in tandem with austerity (Lowndes and Pratchett, 2012; Findlay-King et al., 2018). After a discussion regarding methodology, the context of London, where this research is set, is provided. The paper then lays out the argument that, while austerity has an impact, it is not the sole cause of current threats to urban green space in the British capital. Instead, socio-demographic changes in London, including a population growth rate twice that of other British cities, have put demands on local services that limit the ability to provide discretionary services (ONS, 2016). This section examines benefits and challenges stemming from a prominent response to funding pressures: increased reliance on additional partners, namely friends groups, to manage and maintain London's urban green spaces. The paper concludes with thoughts regarding what this means for future green space management and governance.

\section{Austerity in Britain}

In 2010, Britain's new coalition government imposed a series of sustained reductions in public spending in an effort to aggressively reduce the national deficit and the national debt that resulted from the global financial crisis (Lowndes and Pratchett, 2012; Lowndes and Gardner, 2016). This 'ferocious agenda of public-service cuts' occurred at an 'unprecedented scale' (Featherstone et al., 2012: 177; Lowndes and McCaughie, 2013: 533). Although budgets across all public services in Britain experienced reductions, these cuts were felt acutely by local government, with a proposed $£ 5.5$ billion reduction in funding resulting in a 27 per cent decrease from 2010-2011 to 2014-2015 (Lowndes and Pratchett, 2012; Lowndes and McCaughie, 2013; Platts-Fowler and Robinson, 2016). As such, local government has been 'one of the foremost casualties' of austerity, with cities becoming 'key targets for a punitive politics of austerity' (Tonkiss, 2013: 312; Hastings et al., 2015: 601). 
Some researchers foresee a 'bleak future' for local government, with the sector providing a limited range of services, and individuals and communities taking on increased responsibility for local services (Stoker, 2012, cited in Hastings et al., 2015: 603). Others predict some local services will completely disappear or 'wither on the vine' (Levitas, 2012; Lowndes and McCaughie, 2013: 534). Yet other researchers have assumed a more positive outlook, arguing that local authorities can 'weather the storm' and 'adjust and survive,' while some predict austerity and localism may facilitate innovation and creativity in local government (Lowndes and McCaughie, 2013: 533; Stoker, 2012, cited in Hastings et al., 2015: 602; Hastings et al., 2015; Platts-Fowler and Robinson, 2016).

\section{Discretionary-service cuts}

While budget cuts spanned the range of local council services, the deepest cuts occurred in discretionary functions (NAO, 2014; Brown and Wilson, 2015; Centre for London, 2018). Such non-statutory services include managing and maintaining publicly accessible green spaces (Dempsey, Burton and Selin, 2016). Investment in green space and other public space 'tends to be precarious and disproportionately subject to tight fiscal pressures' (Dempsey and Burton, 2012: 13). Efforts to enhance a city's environment are among the first items cut when cities experience budget problems, and this may reflect low appreciation of the benefits urban green spaces provide (Chiesura, 2004). Research by the Heritage Lottery Fund (HLF) (2016) - the secondlargest funder of public green space in Britain after local authorities - found that 92 per cent of green space managers in the UK had experienced reductions in their revenue budgets between 2013-2015, while three-fourths of local authorities had cut green space staff. Newcastle City Council, for example, has experienced a 90 per cent decrease in its parks and green spaces budget in seven years (NCC, 2018).

Declining local authority resources for green space management and maintenance have not gone unnoticed. Recent headlines warn, 'Green spaces under threat from planning system and funding crisis' (Gosden, 2014), 'England's parks and open spaces have lost $£ 75 \mathrm{~m}$ in cuts since 2010' (Carrington, 2013) and 'Volunteers will need to help preserve London's parks as funding is withdrawn' (Laville, 2017). Parliament also has weighed in. In June 2016, the Communities and Local Government Committee launched an inquiry to examine the impact of recently reduced local authority budgets on public parks and green spaces and 'to consider concerns that their existence is under threat' (CLGC, 2016). Committee chairman Clive Betts tied budget cuts to the discretionary nature of green space provision: "With councils under enormous financial pressures and with no legal obligation to fund and maintain public parks, these precious community resources may be at risk' (CLGC, 2016). As such, austerity has shouldered the blame for reduced spending on urban green spaces.

Although not statutorily prescribed, urban green spaces have been a ubiquitous part of the landscape in Britain since the 19th century. Born out of Victorian liberalism, the 'people's park' movement was meant to address concerns about health and well-being that emerged from the diseased and squalid living conditions of the working classes in industrialising areas (Reeder, 2006: 31). These concerns reached Parliament and, in 1833, the Select Committee on Public Walks recommended public open spaces be provided to counter industrialisation and the crowded, unhealthy conditions in Britain's cities and towns (Walker and Duffield, 1983; CLGC, 2017). By the end of the 19 century, "parks had become quite as much a municipal service as the supply of water, sewerage, and education' (Olsen, 1993: 491). Since then, provision of urban green space has become an embedded responsibility of local authorities (NAO, 2006; James et al., 2009; HLF, 2016; Dempsey, Burton and Selin, 2016). 
Although local authorities' primary consideration under austerity has been protecting statutory duties, some councils have made an effort to shield discretionary services considered political and residential priorities (NAO, 2014). For example, Liverpool City Council chose to protect some discretionary services because they can alleviate pressure on statutory services, thus providing more value for money in the long term (NAO, 2014). Publicly accessible green space can be considered a local priority, as these spaces 'are among the most valued features of the places people live' (DETR, 2000, 4.38). Residents often identify green spaces as the centre of their community, and urban green space remains a popular service (Dunnett, Swanwick and Woolley, 2002; Dempsey, Burton and Selin, 2016). Hastings Borough Council, for example, has been reluctant to cut maintenance of the borough's parks and gardens because of their popularity with residents (NAO, 2014).

\section{Previous eras of austerity}

2010 was not the first time fiscal austerity has affected local government services. Between 1978-1985, local governments in the UK saw a 15 per cent decrease in grants from central government (Talbot and Talbot, 2011). Yet, cuts ushered in by the coalition government beginning in 2010 represented 'the most significant reorganisation of public spending since the Second World War' (Lowndes and Gardner, 2016: 359). The rate of decline of local government budgets 'has been three times greater than that during the recession of the late 1970s and early '80s' (Talbot and Talbot, 2011; Lowndes and McCaughie, 2013: 534; Platts-Fowler and Robinson, 2016).

Corresponding with this, the periods of 1979-1984 and 1989-1994 saw drastic reductions in local authorities' green space budgets (Wilson and Hughes, 2011). Between the late 1970s-1990s, the Conservatives reduced local government expenditure, and parks were seen as 'an easy - non-statutory - target' (Dempsey, Burton and Selin, 2016: 446). Indeed, the latter part of the 20th century 'saw a widespread decline in the quality of urban parks and other green spaces' (Wilson and Hughes, 2011: 207). Budget cuts, along with compulsory competitive tendering, had 'disastrous effects' on urban green spaces in the UK during this period (Jones, 2002: 307; Wilson and Hughes, 2011). The cuts led to degraded facilities, low morale among green space staff, and loss of community contact with green space users and local residents (Jones, 2002). Describing this period, Harding bluntly asserts that '...the last 20 years have seen a massive decline in their [public parks] fortunes. Everything about public parks has got worse' (1999: 3).

As in 2016, Parliament took notice of this deterioration. In 1999, the Environment, Transport and Regional Affairs Select Committee identified a 'spiral of decline' in urban green spaces and blamed this largely on funding (ETRAC, 1999: para. 86). The public and political concern about the decline of parks, green spaces and other public spaces led to these spaces experiencing a 'renaissance' (Harding, 1999; Wilson and Hughes, 2011: 225). This period coincides with the New Labour government's focus on urban green spaces, highlighted by the Urban White Paper in 2000 and establishment of the Urban Green Spaces Taskforce in 2002 (Wilson and Hughes, 2011). The taskforce's recommendations included increasing the amount and sources of funding for urban green spaces (DTLGR, 2002).

As with previous periods of austerity, local authorities now face financial decisions about which services to support and how to do so (Mell, 2016). Local authorities must make 'tough choices on how services are delivered within reduced allocations' (HM Treasury, 2010, cited in Lowndes and McCaughie, 2013: 535). This includes decisions 
about the continued provision and management of publicly accessible urban green spaces.

\section{Localism and the Big Society}

Coupled with austerity in 2010 was the coalition government's aim of reducing regulation and giving local governments more flexibility in use of their budgets (Lowndes and Pratchett, 2012). Key to this was the Localism Bill, meant to encourage communities, citizens and volunteers to assume responsibility for government-run services, particularly those 'threatened with closure' (Lowndes and Pratchett, 2012: 26; Mathers, Dempsey and Molin, 2015). Although local governments would see reduced budgets under austerity, 'they will have much greater freedom to be innovative in the way that they work with and support their communities' (Lowndes and Pratchett, 2012: 25). Transferring responsibility for some local authority services to residents also fits with the coalition government's 'Big Society,' which was about 'empowering communities, redistributing power and fostering a culture of volunteerism' (Cabinet Office, 2010; BBC, 2010; Findlay-King et al., 2018). Under this approach, communities are 'expected to take greater responsibility for their own well-being, as well as for quality of life within neighbourhoods' (Platts-Fowler and Robinson, 2016: 763).

\section{Governance through partnership}

As a popular local service found in most communities across Britain, green space would seem a natural fit for goals of the Big Society and localism, as although green space is a discretionary service, these spaces have proven to benefit well-being and quality of life and are highly valued by residents (Chiesura, 2004; Esbah, Deniz and Cook, 2005; Choumert and Salanié, 2008). Dempsey and Burton observe that 'there is a widespread consensus in theory and policy that a partnership approach to public space management is an effective one' (2012: 15). As such, a prominent way local councils have addressed deep cuts to their green space budgets is through building and expanding partnerships (Dempsey and Burton, 2012; Dempsey, Burton and Selin, 2016). Organisations such as friends-of-the-park groups; environmental-, heritage- and recreation-focused charities; and developers and social landlords have taken on responsibilities for some urban green spaces for which councils used to have sole charge. As the local authority's role has been reduced, these additional partners have become part of an expanded governance of urban green space (Mathers, Dempsey and Molin, 2015).

Friends groups emerged out of the decline of urban parks in the 1990s (Jones, 2002). With local councils unable to maintain their assets, giving responsibility for green space, management to user groups was an 'innovative attempt' to 'share the burden' (Jones, 2002: 307). This adheres to localism's aim of 'reducing the central state and devolving power and responsibility to voluntary groups' (Findlay-King et al., 2018: 158). Friends groups 'are independent community organisations set up by park users and local residents to promote, protect and improve a local green space - in essence to "take ownership" of the space on behalf of local communities and park users' (LGSFGN, 2016). Friends group organise local events, plant bulbs, help increase biodiversity, disseminate information, produce publicity and history pamphlets, work with green space staff, develop visions for improving local spaces, and access resources and funding (LGSFGN, 2016).

Some, however, are sceptical of relying on volunteers to provide public services. Featherstone et al. refer to using community volunteer groups to provide government services as 'austerity localism' (2012: 177). Tonkiss is bolder: 'The ceding of the urban 
field to voluntary effort under the crass rhetoric of the Big Society, in parallel with aggressive retrenchments of local public budgets, tends to outrun any substantive efforts by city governments to more positively promote alternative urban strategies and solutions' (2013: 314). Thus, increased reliance on friends groups is not without question, critique and controversy.

\section{Methodology}

This paper is part of a wider project examining the influences on urban green space delivery and management in Inner London. Through this broader research, data was collected via 50 in-depth, face-to-face, semi-structured interviews with local authority and other government officers, charities and user groups, and home builders and registered social landlords. Of the 50 interviews, 23 were with local authority officers and other government staff, such as from regional and national government agencies; 22 were from charities, community organisations and user groups; and five were developers, registered social landlords or planning consultants.

Initially, council officers whose job descriptions or titles, which were found online or in council documents, indicated they worked in green space planning or management were contacted via cold-calling or cold-emailing. This is a common method of choosing and recruiting interview participants (Longhurst, 2010). Similarly, charities, community organisations, and developers and landlords were approached after identifying their involvement in urban green space issues by reviewing council planning documents, such as planning consultations. Subsequent respondents were identified through snowballing, a useful method for identifying respondents because of a mutual connection (King and Horrocks, 2010). Interviews were conducted between October 2013 and October 2015.

The research was based in three Inner London boroughs: Islington, Tower Hamlets and Wandsworth, although some interview respondents, such as representatives from charities or government agencies, had a broader perspective. These three boroughs were selected based on analysis of the population density in all 33 of London's local authority districts, using data from the Greater London Authority (GLA), and net gain in residential units, using data from the GLA's London Development Database (GLA, 2011a; 2011b). The three boroughs ranked high in both categories, meaning they were dense boroughs continuing to get denser. Thus, green space is delivered and managed in these boroughs with pressure resulting from more people in less space, which was key to the wider research project.

Although 'flexibility is a key requirement of qualitative interviewing,' a topic guide was used to outline the main subjects to cover during interviews and to provide standard wording for questions (King and Horrocks, 2010: 35; Longhurst, 2010). Each interview was recorded and transcribed, and a coding framework based on emergent themes was developed. Using NVIVO software, the codes were applied to the interview data. Through this thematic analysis, patterns were identified in the data, resulting in the findings presented below.

A secondary method used involved reviewing documents, which can provide context and frame data from other sources, including interviews (Silverman, 2004; Robson, 2011). Types of documents reviewed included planning applications, officers' reports and decision notices; strategic plans, including open-space strategies; charity reports and documents; minutes from meetings; and websites. By examining these documents alongside interview data, a richer picture developed regarding issues and concerns 
arising from cuts to green space resources and the increasing reliance on non-council partners.

\section{The context of London}

This research is based in London, where publicly accessible urban green spaces have featured prominently for nearly 200 years (Wilson and Hughes, 2011). The unsanitary conditions that prompted Parliament to support establishing public open spaces across industrialising areas existed in London, particularly in the East End, where 400,000 people lived in 'a complete state of insolvency and hopeless poverty' (Greville, 1874, cited in Poulsen, 1976: 9). Given these conditions, more than 30,000 people, including local residents and social reformers, successfully petitioned Queen Victoria to establish a park and, in 1840, the Commission of Woods and Forests authorised Victoria Park to be created as a 'Memorial to the Sovereign' (Poulsen, 1976).

Located in what is now the London borough of Tower Hamlets, Victoria Park opened in 1845, becoming one of the first green spaces in England funded by the government expressly for public use by the local community (Poulsen, 1976). Since Victoria Park opened in the mid-19th century, public green space has become an enduring feature of London's urban landscape, and has remained a decidedly local function (LAEC, 2017). Today, all 33 local governments in London, including the City of London, provide publicly accessible green space for residents, workers and visitors. As recently as 2006, the public sector - predominantly local authorities - provided 85 per cent of funding for Britain's local parks and green spaces, illustrating how embedded this funding structure has become (NAO, 2006). These spaces consistently rank high on councils' resident satisfaction surveys (interview respondents).

Despite the wide-ranging benefits green spaces deliver and the popularity of these spaces with Londoners, funding remains susceptible to cuts. Between 2009-2010 and 2013-2014, London local government had a 37 per cent per capita reduction in service funding from central government (Fitzgerald and Lupton, 2015: 597). London local authority budgets fell 44 per cent between 2010-2011 and 2015-2016 (Brown and Wilson, 2015; London Councils, 2015). The largest percentage cuts have come from discretionary services, such as providing green space (Fitzgerald and Lupton, 2015; Centre for London, 2018).

\section{Findings and discussion}

\section{Beyond austerity}

The depth and timing of recent cuts to local authorities' budgets have contributed to pressure on London's urban green spaces (LAEC, 2016). London councils' spending on open space, which includes green space, decreased 18 per cent in four years, including a reduction of more than 10 per cent in 2014-2015 (London Councils, 2015; LAEC, 2016). Nearly every interview respondent cited austerity as a significant cause for this pressure on green space resources. The National Federation of Parks and Green Spaces (NFPGS) (2016) maintains that 'this underfunding crisis is hitting all the fundamental pillars of effective green space management,' including skilled front-line staff, contract management, and back-office support for funding bids and coordination with community organisations and volunteers. 


\section{p. 211. Blame it on austerity? Examining the impetus behind London's changing green space governance}

Yet, focusing on austerity overlooks a structural, deeper and longer-term reason for pressure on London's green spaces. At the same time local councils have seen their budgets reduced through austerity-related cuts, they also have experienced growing and changing populations, which has led to rising demands on statutory services (Lowndes and McCaughie, 2013). This impact of urban change gets lost in the discussion about green space, as blaming austerity suggests an easier solution: simply reverse the cuts and restore revenue lost from austerity. Indeed, previous periods of budgets cuts were seen by local government as 'a temporary crisis caused by economic conditions that would pass' - and funding typically was restored (Talbot and Talbot, 2011: 70). Yet, this ignores the growing, sustained demand on services stemming from a changing London.

\section{Changing populations, rising demands}

The population of London grew from 6.8 million in 1988 to 8.8 million in 2016, and presently stands as the largest in the city's history (GLA, 2017a). The population is projected to further increase to 10 million by 2030 (GLA, 2017b). Changing demographics are spurring 'a sharp increase in citizen demand' for statutory services, squeezing local authority budgets and leaving less money for discretionary services (Lowndes and McCaughie, 2013: 533). Indeed, spending on adult and children social care is the largest expenditure in London councils' budgets, comprising 62 per cent in 2017-2018, an increase from 54 per cent in 2010-2011 (Centre for London, 2018). This trend is expected to continue, with London's over-65 population projected to grow by 21 per cent over the next decade, while the school-age population will experience a projected 12 per cent growth over the same period (London Councils, 2013). Thus, even without austerity, green space budgets would continue to be stretched as local councils spend an increasing proportion of their budgets on statutory functions.

Several respondents said cuts would not have been as deep if providing green space was a statutory requirement: 'Because parks are not a statutory service, it has taken, some would say, more than its fair share of cuts' (respondent 44, green space officer). However, all statutory services are unlikely to be covered by local authority budgets in the near future (LGA, 2014). Austerity may have an impact by reducing the overall size of the pie, but socio-demographic changes in London already were consuming a larger slice, and will continue to do so as the capital's population grows and changes.

London councils have responded to pressure on their green space budgets in myriad ways. This includes reducing staff through redundancies, early retirements or unfilled vacancies; renegotiating maintenance contracts; bringing maintenance functions in house; reducing maintenance services and schedules; placing management of green spaces into a trust; selling green spaces and facilities within them; and sharing or combining services with other local authorities (LAEC, 2016; LAEC, 2017; interview respondents).

\section{'Friends' groups}

This research focuses on one prominent way local councils have addressed declining green space budgets: building and expanding partnerships with user groups and community organisations. Concerns about decreasing budgets and increasing pressures have accelerated an evolving green space governance by necessitating local authorities rethink how they deliver urban green spaces. This has opened the door more widely to additional partners, mirroring a broader move in environmental governance that involves actors beyond government (Fors et al., 2015; Mathers, Dempsey and Molin, 2015). For example, from 2013-2015, half of UK local authorities had transferred outdoor sports facilities to community groups, and almost one-third were considering transferring parks to community groups (HLF, 2016). 
Yet, even before austerity, the number of user groups formed to work with green spaces was increasing (respondent 2, senior staff, regional charity; respondent 32, senior staff, national charity). Nationally, the friends movement 'mushroomed' in the 2000s, from a few hundred groups to more than 6,000 today (NFPGS, 2012). In London, more than 600 friends groups existed as of July 2017 (LAEC, 2017; respondent 2; respondent 32).

The form of relationships between councils and user groups varies across - and even within - boroughs. For example, in Wandsworth, the Friends of Wandsworth Park maintain a flower bed, while the Friends of Tooting Common helped secure funding for new ecology ponds. In Tower Hamlets, the council has several service-level agreements with local organisations, such as Friends of Tower Hamlets Cemetery Park, which manages the space and employs staff. The Friends of Arnold Circus, a charitable community organisation formed by residents in 2004, took over day-to-day maintenance of the bandstand and surrounding Boundary Gardens from Tower Hamlets Council after the space became run-down and a magnet for antisocial behaviour (respondent 39, green space officer; respondent 40, senior staff, local charity).

Figure 1: Arnold Circus and Boundary Gardens are managed and maintained by the Friends of Arnold Circus in Tower Hamlets (author's photo)

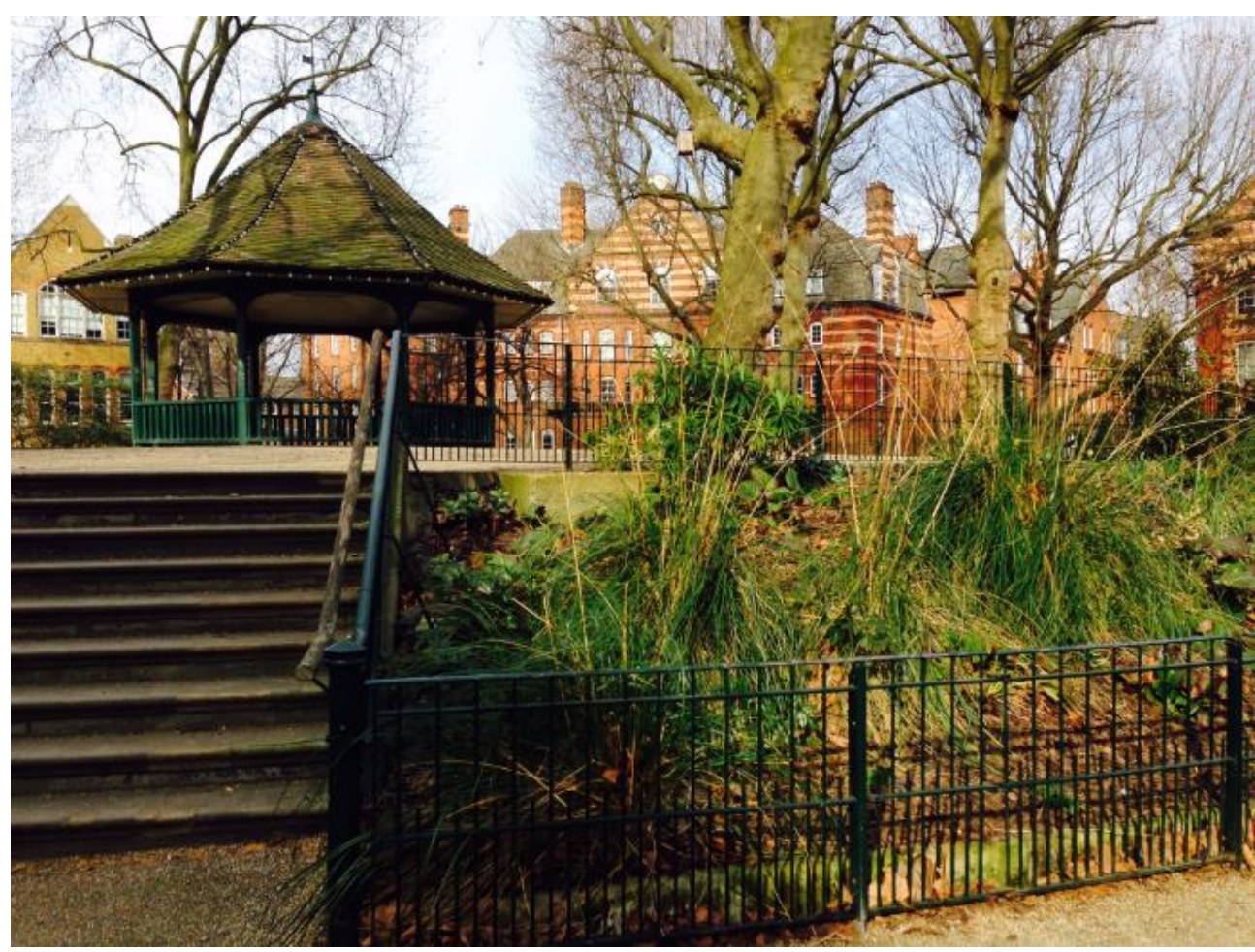

\section{Benefits of expanded governance}

Respondents identified several benefits from friends groups playing a more prominent role in the governance of London's green spaces. Community organisations often can provide more targeted attention to a green space than a local authority can, and some councils actively encourage establishing friends groups. 
p. 213. Blame it on austerity? Examining the impetus behind London's changing green space governance

Horticulturally they [friends groups] can improve a [green] space enormously and have a bit of individual character that we couldn't necessarily do trying to manage 80-odd parks and open spaces (respondent 31, green space manager).

This has an impact as budget cuts lead to a loss of front-line skills within the council.

The role and the function of the client side has been pushed out, which means all that knowledge and skills go. People, friends groups, have a far larger stake in the future of parks because they are a remnant of local knowledge of the parks. They are becoming a stronger force (respondent 2, senior staff, regional charity).

Several respondents viewed user groups as a way to shift some of the funding burden away from the council. Similarly, others observed that user groups can access funding local councils cannot.

If they do all the horticultural works for the park, we pay them the equivalent unit rates for doing that work and then they tend to buy plants and improve the park. It works quite well for us because they just invested that money back into the space and the groups get a little bit of core funding to get their activities going (respondent 31).

Figure 2: One of the Friends of Battersea Park's roles is to raise improvement funds for the large green space in the London borough of Wandsworth (author's photo)
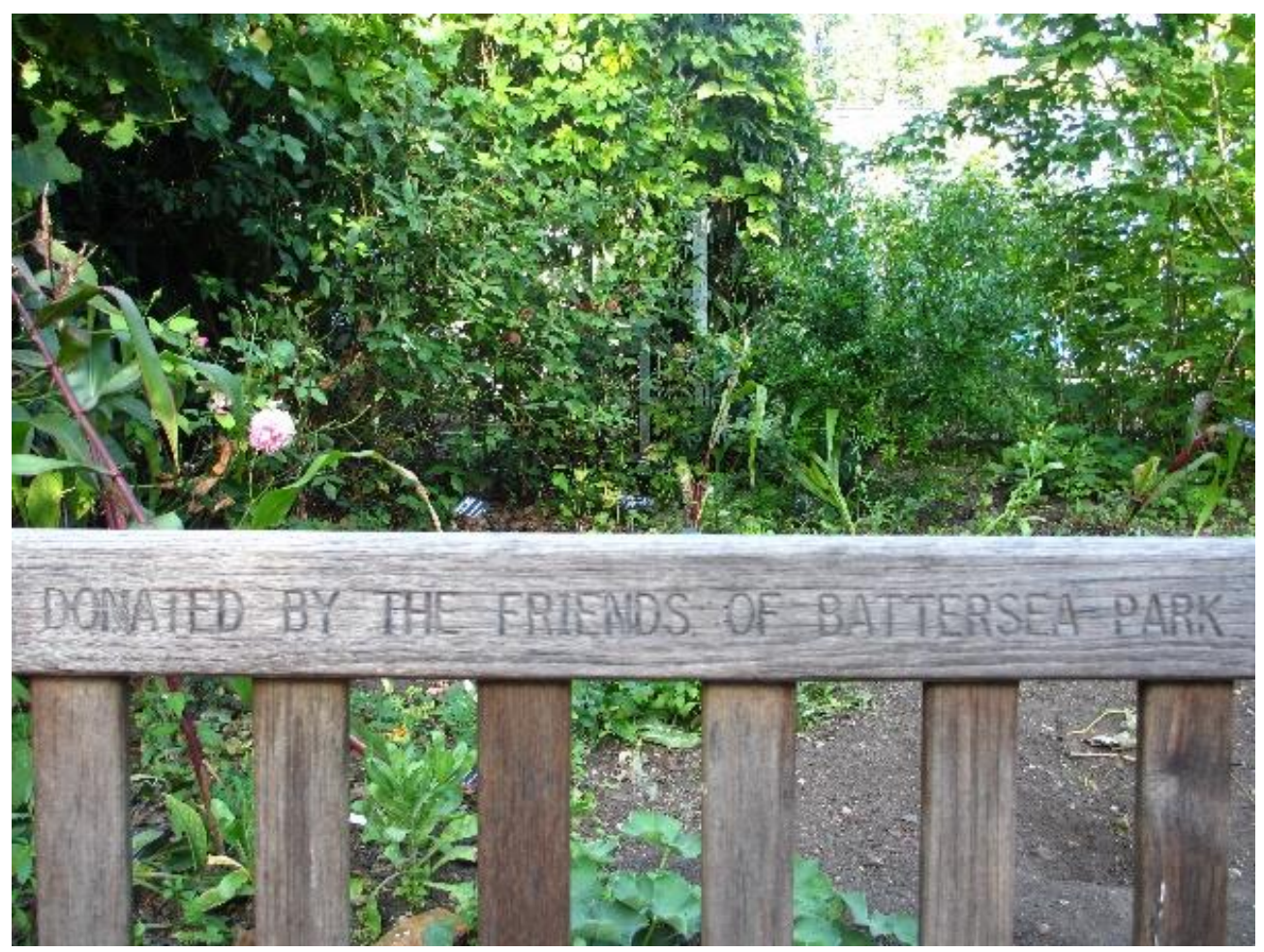
Local groups have revitalised neglected spaces in London, making these spaces vibrant parts of the local community's infrastructure in a way that the local authority could not. Respondent 39 (green space officer) discussed how this occurred with Arnold's Circus:

We [the local authority] approached the community and said, 'why don't you take ownership of this space, not legally, but you lead on improvements, do what you want, how you want to use this space, and we will take a supporting role.' The community got together and set themselves up as a friends group and they've just done amazing things with it. They're holding regular events and activities, antisocial behaviour has gone down and people have taken greater ownership of it.

Figure 3: Volunteers maintain a section of Bramford Community Gardens on behalf of Wandsworth Council (author's photos)
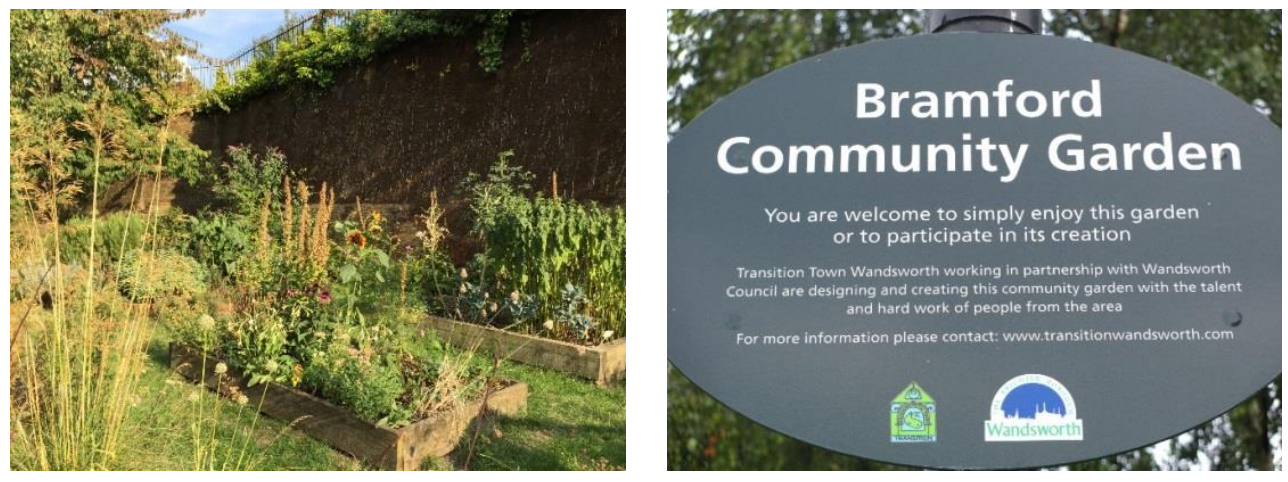

\section{Challenges of expanded governance}

Although an expanded green space governance can have a positive impact, respondents also discussed how increasing the responsibility of community organisations and volunteer groups presents challenges. These challenges can be overlooked, however, as local authorities and residents concentrate on green space management in the short term as council resources decline.

\section{Thinking local}

The benefits of green spaces do not accrue solely to the immediate community. Benefits such as air and water filtration, urban cooling, and biodiversity enhancement extend beyond the local neighbourhood and support the city or region as a whole (see Kambites and Owen, 2006). The increasing role of friends groups has ramifications for whether green spaces are managed with a strategic perspective, particularly as recognition of the citywide and regional environmental, economic and societal benefits of green space become more understood. The London Parks and Green Space Forum (LPGSF) (2012) found that the primary reason members of friends group volunteered was to improve their local park, demonstrating that these groups typically are concerned with their immediate neighbourhood, but may not consider how their local green space can contribute as part of a larger, London-wide system. Although a green space may be the centre of a community, it provides valuable environmental services, such as climate change mitigation, that require a strategic approach (Pincetl and Gearin, 2005; Kambites and Owen, 2006; Gill et al., 2007; Rutt and Gulsrud, 2016). 
p. 215. Blame it on austerity? Examining the impetus behind London's changing green space governance

The penny hasn't dropped for a lot of them [user groups] that, although local is important ... there's a bigger picture here, there's more at stake (respondent 2).

\section{Focus on small spaces}

Friends groups also are more likely to take on management of smaller green spaces, or small plots within larger green spaces. This can lead to smaller spaces being managed for local use only, overlooking the critical work smaller spaces do in a broader, interconnected system of green spaces (Van Herzele and Wiedemann, 2003; Giles-Corti et al., 2005; respondent 23, senior staff, national charity). Yet, small green spaces provide linkages necessary for recreation, such as walking and cycling greenways, and for environmental services, including flood protection and urban wildlife corridors (Kaplan, 1984; Turner, 1995; Niemelä et al., 2010; Peschardta et al., 2012). Residents encounter smaller, local spaces - 'nature-at-the-doorstep' - more frequently and these spaces can have more impact on their daily lives than larger, but more distant, green spaces (Kaplan, 1984: 189; Burgess et al., 1988; Van den Berg et al., 2007).

That's a really powerful thing, this sense of linking up open spaces, because it means small spaces can become part of the continuum and they can be really effective in giving people a big recreation experience, a big outdoor experience (respondent 22, landscape architect, national charity).

\section{Commitment issues}

Community groups may not have the capacity for long-term commitment that local government does (Rosol, 2012; Fors et al., 2015; LAEC, 2017). Yet, a long-term planning perspective is essential for managing green spaces, particularly for environmental services (McMahon, 2000; Dempsey and Burton, 2012; Dempsey, Burton and Selin, 2016).

People who think they're going to lose something will get together and fight for it. And, that is the catalyst for a lot of formation of action groups and friends groups, and often many fall apart once they've got what they wanted (respondent 2).

The local authority also may have a lack of commitment to a partnership approach, stemming from a perceived loss of power, possession of expertise and lack of training in managing volunteers (Jones, 2002). Council officers, while increasingly dependent on friends groups, may not see such groups as actual partners and may have a paternalistic attitude to volunteers (Jones, 2002). Thus, despite having increasing responsibilities, friends groups may not be reasonably empowered (Arnstein, 1969).

A lot of the ones [friends groups] we have got now have come from a demand for people to get their hands in the soil and we've had to manage that demand in a different way. ... We're very clear on what we mean by providing a public park and it isn't about community gardening for us. ... It's always been hard for us to have those community groups engaged in practical delivery (respondent 19, green space manager).

\section{Continuing costs}

Volunteers may move away from the neighbourhood or experience changes in their circumstances, such as new job or family responsibilities. As a result, a local council might need to 'pick up the pieces' by bringing management in house or dedicating resources to finding, educating and supporting other community volunteers (LAEC, 
2017: 25). This leads to costs for the local authority and can disrupt maintenance schedules and funding, particularly if the friends group had responsibility for securing grants. Simply managing community groups consumes council time and resources, including contract-management costs.

We've got a tiny little site ... that has developed a very strong friends group and they've got very strong opinions. [We've spent] a huge amount of officer time on one relatively small park, and it means when you're doing that, there's less time for other parks (respondent 31).

Many local authorities have cut their budgets for volunteer management. Thus, as local authorities have increased use of friends groups, they simultaneously are seeing cuts to their budgets to support community volunteers. Volunteering in London's green space already was plateauing in 2012 'because of lack of supportive resources and capacity' (LPGSF, 2012; NFPGS, 2016). Indeed, while friends groups may be willing to increase volunteering in their parks, they also want more supervision and funding (LPGSF, 2012). Yet, without a budget and staff to manage volunteers, local authorities will be unable to use more volunteers (LPGSF, 2012). Ultimately, 'if local government loses staff, it curtails what they can do with volunteers,' and friends groups will have difficulty sustaining their commitment to green space management and maintenance (LPGSF, 2012: 9).

\section{Lack of community representation}

Local groups do not necessarily represent the community. For example, LPGSF (2012) found that 48 per cent of friends groups volunteers were retired. However, no London borough has 48 per cent retired population. With fewer resources, council officers cannot devote time to ensuring the whole community's interests are considered and, thus, the voices of only active volunteers may prevail. As such, the people localism most empowers 'are likely to be those with the resources, expertise and social capital to become involved in the provision of services and facilities' (Featherstone et al., 2012: 178). This has particular ramifications for disadvantaged and deprived communities, which tend to be hardest hit by austerity (Featherstone et al., 2012). Thus, an expanded green space governance can actually exacerbate inequality (Clifford and Tewdwr-Jones, 2014).

You've got a lot of articulate, demanding residents with very high expectations who will see parks being used in a certain way, then you've got a large proportion of the community who are ... worried about getting food on their plate or heat in their house, not whether a local park is being maintained to how you want it. ... You've always got to try and speak for those that haven't got a voice (respondent 31).

\section{Lack of consensus}

In its aim to 'give local councils the freedom to spend money on the things that matter to local people,' localism implies homogenous preferences among the local community (Conservative Party, 2009: 3; Featherstone et al., 2012). Yet, London's communities are socially, culturally and economically diverse, making it unlikely that local residents will develop a consensus over how to manage an urban green space.

Around one square ... we've got three friends groups and they all hate each other. You've got some who say, 'why are we putting any sport facility in, why are putting any play equipment in?' And you have some that are going, 'well, we want play equipment everywhere so kids can play.' I mean, you're damned if you do, 
damned if you don't. The constraint, then, is that we [the local council] are going to be spending a load of money and we will please very few of the people (respondent 44).

There is a disconnect between the idea of localism and what locals actually want. An increased reliance on friends groups implies these organisations want to play a more prominent role in providing green space. However, friends groups do not want 'to substitute for well-trained and resourced staff, or to feel exploited as cheap labour' (NFPGS, 2016). Local residents do not want their local authority to relinquish responsibility of green space management. Instead, they prefer their volunteer activities complement, rather than replace, the local authority's efforts.

\section{Conclusion}

Austerity measures imposed since 2010 have put pressure on London's urban green spaces. However, focusing on fiscal austerity as the root of urban green spaces' existing funding challenges downplays the impact of increased cost pressures stemming from socio-demographic changes occurring in the British capital (Hastings et al., 2015). The 'double whammy' of austerity and urban change has resulted in a 'massive shortfall in resources' for London local authorities and particularly for nonstatutory services, including providing green space (Hastings et al., 2015: 602).

Local authorities, the traditional provider of publicly accessible urban green spaces, have looked beyond the public sector to manage these spaces. Community organisations, namely friends groups, which already had become increasingly involved in urban green space management, have stepped further into the role. Including such organisations in an expanding green space governance can enhance community interaction, and revitalise neglected spaces, which contributes to urban sustainability (Chiesura, 2004; Baycan-Levent et al., 2009; Dempsey, 2013). However, such community organisations are not intended to provide public services in the same way a public-sector body does, and this presents challenges for the long-term viability of an expanded green space governance that relies increasingly on volunteer-based organisations.

HLF closed its Parks for People programme in 2018, and from 2020 the Central Government Revenue Support Grant will decrease, thus local governments will need to raise more income locally (HLF, 2018; LGA, 2018). Reacting to austerity-related reductions in green space budgets by expecting local residents to provide public services at an increasing rate ignores the larger structural and long-term funding issues emerging because of socio-demographic changes. As local authority budgets decrease and populations grow and change, there is a danger of over-reliance on friends groups. A fundamental rethinking of how green space is funded and managed is needed. This must be innovative and not simply shift the burden from local authorities to community organisations, whose resilience to provide local services is uncertain (Jones, 2002; Fitzgerald and Lupton, 2015).

Ultimately, before considering friends groups as a remedy for green space delivery and management, more research is needed to understand the implications of their growing involvement in green space governance. Better analysis of the actual costs of local authorities 'sharing the burden' for green space management and maintenance would be telling, as would examining what happens to a strategic perspective when local groups have more influence in green space planning (Jones, 2002: 307). More research is needed on the voluntary sector's resilience and viability as a long-term partner in green space management. 
This is not to imply that there is no role for friends groups. Indeed, as a popular asset that benefits all residents whether they use green space or not, urban green spaces are primed for community involvement. However, rather than turning to friends groups to plug the hole of funding losses, local authorities need to think longer term and recognise that the traditional method of green space funding was unsustainable even before austerity. Austerity has intensified the pressure, revealing the precarious position discretionary services were in already. The role of a strategic entity, such as a local authority, to oversee the planning, management, maintenance, funding and use of green space is critical. Friends groups can complement this, but they should not be seen as a permanent, sustainable solution to London's urban green space challenges.

\section{Acknowledgements}

Many thanks to the interview respondents and organisations who granted me interviews and permitted me to use this information in my research; and a sincere thank you to the anonymous readers at PPP whose feedback resulted in a much stronger article.

*Correspondence address: Meredith Whitten, London School of Economics and Political Sciences, Department of Geography and Environment, Houghton Street, London WC2A 2AE. Email: mwhitten@alumni.LSE.ac.uk / @urbanparksgirl

\section{References}

Arnstein, S. (1969) A ladder of citizen participation. Journal of the American Institute of Planners, 35:4, 216-224. DOI: 10.1080/01944366908977225.

Baycan-Levent, T., Vreeker, R. and Nijkamp, P. (2009) A multi-criteria evaluation of green spaces in European cities. European Urban and Regional Studies, 16, 2, 192-213. Available at: https://doi.org/10.1177/0969776408101683

BBC News (2010) David Cameron launches Tories' 'big society' plan. BBC News, 19 July 2010. Available at: https://www.bbc.co.uk/news/uk-10680062 [Accessed: 25/05/2018]

Brown, R. and Wilson, B. (2015) Running on fumes? London council services in austerity. London: Centre for London. Available at: https://www.centreforlondon.org/wpcontent/uploads/2016/08/CFL3888_Running-onfumes short paper 12.11.15 WEB-1.pdf [Accessed: 22/06/2017]

Bullock, C. (2008) Valuing Urban Green Space: Hypothetical Alternatives and the Status Quo. Journal of Environmental Planning and Management, 51, 1, 15-35. Available at: https://doi.org/10.1080/09640560701712242

Burgess, J., Harrison, C.M. and Limb, M. (1988) People, parks and the urban green: a study of popular meanings and values for open spaces in the city. Urban Studies, 25, 6, 455-473. Available at: https://doi.org/10.1080/00420988820080631

Cabinet Office (2010) Building the Big Society. Policy paper. London: Cabinet Office. Available at: https://www.gov.uk/government/publications/building-the-bigsociety [Accessed: 25/10/2018]

Carrington, D. (2013) England's parks and open spaces have lost $£ 75 \mathrm{~m}$ in cuts since 2010. The Guardian, 19 Nov 2013. Available at: https://www.theguardian.com/environment/2013/nov/19/england-parksspending-cuts [Accessed: 28/05/2017] 
Centre for London. (2018) The London Intelligence. London. Available at: https://www.centreforlondon.org/wp-content/uploads/2018/05/Issue-4-TLI.pdf [Accessed: 10/06/2018]

Chiesura, A. (2004) The role of urban parks for the sustainable city. Landscape and Urban Planning, 68, 1, 129-138. Available at: https://doi.org/10.1016/j.landurbplan.2003.08.003

Choumert, J. and Salanié, J. (2008) Provision of urban green spaces: some insights from economics. Landscape Research, 33, 3, 331-345. Available at: https://doi.org/10.1080/01426390802045996

Clifford, B. and Tewdwr-Jones, M. (2014) The collaborating planner? Practitioners in the neoliberal age. London: Policy Press.

Communities and Local Government Committee (CLGC) House of Commons (2016) Future of public parks inquiry launched. London. Available at: https://www.parliament.uk/business/committees/committees-a-z/commonsselect/communities-and-local-government-committee/news-parliament2015/public-parks-launch-16-17/ [Accessed: 17/04/2018]

Communities and Local Government Committee (CLGC) House of Commons (2017). Public parks. Availa London. ble at: http://www.publications.parliament.uk/pa/cm201617/cmselect/cmcomloc/45/ 45.pdf. [Accessed: 17/04/2018]

Conservative Party (2009) Control shift: returning power to local communities. Responsibility Agenda, Policy green paper no. 9. The Conservative Party: London.

Crompton, J. L. (2001) The Impact of Parks on Property Values: A Review. Journal of Leisure Research, 33, 1, 1-31. Available at: https://doi.org/10.1080/00222216.2001.11949928

De Bon, H., Parrot, L. and Moustier, P. (2009) Sustainable urban agriculture in developing countries. A review. Agron. Sustain. Dev., 30, 1, 21-32. Available at: https://doi.org/10.1051/agro:2008062

Dempsey, N. (2013) Book Review: Social Sustainability in Urban Areas: Communities, Connectivity and the Urban Fabric. Urban studies, 50, 5, 1089-1092. Available at: http://www.jstor.org/stable/26144270

Dempsey, N. and Burton, M. (2012) Defining place-keeping: the long-term management of public spaces. Urban Forestry \& Urban Greening, 11, 11-20. Available at: https://doi.org/10.1016/j.ufug.2011.09.005

Dempsey, N., Burton, M. and Selin, J. (2016) Contracting out parks and roads maintenance in England. International Journal of Public Sector Management, 29, 5, 441-456. Available at: https://doi.org/10.1108/IJPSM-02-2016-0029

Department for Transport, Local Government and the Regions (DTLGR) (2002) Green Spaces, Better Places: Final Report of the Urban Green Spaces Taskforce. London: TSO.

Department of the Environment, Transport and the Regions (DETR) (2000) Our Towns and Cities: The Future - Delivering an Urban Renaissance. London: DETR.

Dunnett, N., Swanwick, C. and Woolley, H. (2002) Improving urban parks, play areas and green spaces. London: Department for Transport, Local Government and the Regions.

Environment, Transport and Regional Affairs Committee, House of Commons (ETRAC). (1999) Report on Town and Country Parks - Twentieth Report (Two Views - The Park in Decline). House of Commons: London. Available at: https://publications.parliament.uk/pa/cm199899/cmselect/cmenvtra/477/477 02.htm [Accessed: 12/10/2016]

Esbah, H., Deniz, B. and Cook, E.A. (2005) Isolation trends of urban open spaces. Proceedings of the ISPRS joint conference, Tempe, Arizona. Available at: http://www.isprs.org/proceedings/XXXVI/8-W27/esbah02.pdf 22/07/2016] 
Featherstone, D., Ince, A., Mackinnon, D., Strauss, K. and Cumbers, A. (2012) Progressive localism and the construction of political alternatives. Transactions of the Institute of British Geographers, New Series, 37, 2, 177-182. Available at: https://www.jstor.org/stable/41427938

Findlay-King, L., Nichols, G., Forbes, D. and Macfadyen, G. (2018) Localism and the Big Society: the asset transfer of leisure centres and libraries - fighting closures or empowering communities? Leisure Studies, 37, 2, 158-170. DOI: 10.1080/02614367.2017.1285954.

Fitzgerald, A. and Lupton, R. (2015) The Limits to Resilience? The Impact of Local Government Spending Cuts in London. Local Government Studies, 41, 4, 582 600. DOI: 10.1080/03003930.2015.1040154.

Fors, H., Molin, J.F., Murphy, M.A. and Konijnendijk van den Bosch, C. (2015) User participation in urban green spaces - for the people or the parks? Urban Forestry \& Urban Greening, 14(3), 722-734. Available at: https://doi.org/10.1016/j.ufug.2015.05.007

Giles-Corti, B., Broomhall, M.H., Knuiman, M., Collins, C., Douglas, K., Ng, K., Lange, A. and Donovan, R.J. (2005) Increasing walking: how important is distance to, attractiveness, and size of public open space? American Journal of Preventive Medicine, 28, 2, 169-176.

Gill, S., Handley, J., Ennos, A. and Pauleit, S. (2007) Adapting Cities for Climate Change: The Role of the Green Infrastructure. Built Environment, 33, 1, 115-133. Available at: https://doi.org/10.2148/benv.33.1.115

Gosden, E. (2014). Green spaces under threat from planning system and funding crisis. The Telegraph, 1 September 2014. Available at: https://www.telegraph.co.uk/news/earth/environment/11065039/Greenspaces-under-threat-from-planning-system-and-funding-crisis.html. [Accessed: 28/05/2018]

Greater London Authority (GLA) (2011a) Land area and population density, borough. London: Greater London Authority. Available at: http://data.Iondon.gov.uk/datastore/package/land-area-and-population-densityborough [Accessed: 4/06/2012].

Greater London Authority (2011b) London development database. London: Greater London Authority. Available at: https://www.london.gov.uk/what-wedo/planning/london-plan/london-development-database [Accessed: 5/06/2012].

Greater London Authority (2017a) London borough profiles. London: Greater London Authority. Available at: https://data.london.gov.uk/dataset/london-boroughprofiles [Accessed: 18/06/2018].

Greater London Authority (2017b) 2016-based Trend Projection Results. London: Greater London Authority. Available at: https://www.Iondon.gov.uk/sites/default/files/2016_based_trend_projection_re sults.pdf [Accessed: 12/04/2018].

Harding, S. (1999) Towards a renaissance in urban parks. Cultural Trends, 9, 35, 1-20. Available at: https://doi.org/10.1080/09548969909365086

Hastings, A., Bailey, N., Gannon, M., Besemer, K. and Bramley, G. (2015) Coping with the Cuts? The Management of the Worst Financial Settlement in Living Memory. Local Government Studies, 41, 4, 601-621. DOI: 10.1080/03003930.2015.1036987.

Heidt, V. and Neef, M. (2008) Benefits of urban green space for improving urban climate. In: M.M. Carreiro, Y.C. Song and J. Wu, (eds.) Ecology, Planning, and Management of Urban Forests. New York: Springer.

Heritage Lottery Fund (HLF) (2016) State of UK Public Parks. London: HLF. Available at: https://www.hlf.org.uk/state-uk-public-parks-2016 [Accessed: 09/09/2017] 
Heritage Lottery Fund (2018) Changes to our grant making. London: HLF. Available at: https://www.hlf.org.uk/about-us/our-strategy/changes-our-grant-making [Accessed: 12/06/2018]

Hillsdon, M. P. (2006) The relationship between access and quality of urban green space with population physical activity. Public Health, 120, 12, 1127-1132. Available at: https://doi.org/10.1016/j.puhe.2006.10.007

James, P., Tzoulas, K., Adams, M.D., Barber, A., Box, J., Breuste, J., Elmqvist, T., Frith, M., Gordon, C., Greening, K.L., Handley, J., Haworth, S., Kazmierczak, A.E., Johnston, M., Korpela, K., Moretti, M., Niemela, J., Pauleit, S., Roe, M.H., Sadler, J.P. and Ward Thompson, C. (2009) Towards an integrated understanding of green space in the European built environment. Urban Forestry and Urban Greening, 8, 2, 65-75. Available at: https://doi.org/10.1016/i.ufug.2009.02.001

Jones, R. (2002) Partnerships in action: strategies for the development of voluntary community groups in urban parks. Leisure Studies, 21, 3-4, 305-325. Available at: https://doi.org/10.1080/0261436022000030623

Kambites, C. and Owen, S. (2006) Renewed prospects for green infrastructure planning in the UK. Planning Practice and Research, 21, 4, 483-496. Available at: https://doi.org/10.1080/02697450601173413

Kaplan, R. (1984) Impact of Urban Nature: A Theoretical Analysis. Urban Ecology, 8, 3, 189-197. Available at: https://doi.org/10.1016/0304-4009(84)90034-2

King, N. and Horrocks, C. (2010) Interviews in qualitative research. Los Angeles: Sage.

Laville, S. (2017) Volunteers will need to help preserve London's parks as funding is withdrawn - report. The Guardian, 5 July 2017. Available at: https://www.theguardian.com/uk-news/2017/jul/05/volunteers-will-need-to-

help-preserve-londons-parks-as-funding-is-withdrawn-report [Accessed: 28/05/2017]

Levitas, R. (2012) The Just's Umbrella: Austerity and the Big Society in Coalition policy and beyond. Critical Social Policy, 32, 3, 320-342. Available at: https://doi.org/10.1177/0261018312444408

Local Government Association (LGA) (2014) Under pressure: How councils are planning for future cuts. London: LGA. Available at: https://www.local.gov.uk/sites/default/files/documents/under-pressure-howcounci-471.pdf [Accessed: 5/12/2018]

Local Government Association (LGA) (2018) Local services face further $£ 1.3$ billion government funding cut in 2019/20. London: LGA. Available at: https://www.local.gov.uk/about/news/local-services-face-further-ps13-billiongovernment-funding-cut-201920 [Accessed: 22/10/2018]

London Assembly Environment Committee (LAEC) (2016) Green Spaces - scoping note. London Assembly: London. Available at: https://www.london.gov.uk\%2Fsites\%2Fdefault\%2Ffiles\%2Fgreen_spaces investi gation_-_scoping_paper.pdf\&usg=AOvVaw1E4Z-1FCBx [Accessed: 25/02/2017]

London Assembly Environment Committee (2017) Park life: ensuring green spaces remain a hit with Londoners. London: London Assembly.

London Councils (2013) London's Population. London Councils. Available at: https://www.londoncouncils.gov.uk/node/1551 [Accessed: 15/05/2018]

London Councils (2015) Spending Review 2015: London Councils' Submission to HM Treasury. London: London Councils. Available at: https://www.londoncouncils.gov.uk/sites/default/files/Policy\%20themes/Local\% 20government\%20finance/LC Spending Review01d.pdf [Accessed: 15/04/2018]

London Green Spaces Friends Group Network (LGSFGN) (2016) Written evidence submitted to the Communities and Local Government Committee, Public Parks inquiry. LGSFGN: London. Available at: http://data.parliament.uk/writtenevidence/committeeevidence.svc/evidencedoc 
p. 222. Blame it on austerity? Examining the impetus behind London's changing green space governance

ument/housing-communities-and-local-government-committee/publicparks/written/39618.pdf [Accessed: 15/04/2018]

London Parks and Green Spaces Forum (LPGSF) (2012) Volunteering in London's Green Spaces. LPGSF: London. Available at: https://www.Ipgsf.org.uk/wpcontent/uploads/2016/09/Volunteering-in-London-2012Final.pdf [Accessed: 28/05/2018]

Longhurst, R. (2010). Semi-structure interviews and focus groups. In: N. Clifford, S. French and G. Valentine, (eds.) Key methods in geography. London: SAGE Publications Ltd.

Lowndes, V. and Gardner, A. (2016) Local governance under the Conservatives: superausterity, devolution and the 'smarter state.' Local Government Studies, 42, 3, 357-375. DOI: 10.1080/03003930.2016.1150837.

Lowndes, V. and McCaughie, K. (2013) Weathering the perfect storm? Austerity and institutional resilience in local government. Policy \& Politics, 4, 4, 533-549. Available at: https://doi.org/10.1332/030557312X655747

Lowndes, V. and Pratchett, L. (2012) Local Governance under the Coalition Government: Austerity, Localism and the 'Big Society'. Local Government Studies, 38, 1, 21-40. DOI: 10.1080/03003930.2011.642949.

Mathers, A., Dempsey, N. and Molin, J.F. (2015) Place-keeping in action: evaluating the capacity of green space partnerships in England. Landscape and Urban Planning, 139, 126-136. Available at: https://doi.org/10.1016/j.landurbplan.2015.03.004

McMahon, E.T. (2000) Green infrastructure. Planning Commissioners Journal, 37, 4-7.

Mell, I. (2016) Financing green infrastructure in times of austerity: the case of Liverpool. Biotope City Journal. (18 January 2016). Available at: http://www.biotope-city.net/gallery/financing-green-infrastructure-times-austerity. [Accessed: 25/10/2018]

National Audit Office (NAO) (2006) Enhancing Urban Green Space. London: The Stationery Office. Available at: https://www.nao.org.uk/wpcontent/uploads/2006/03/0506935.pdf [Accessed: 22/04/2018]

National Audit Office (NAO) (2014) The impact of funding reductions on local authorities. London: The Stationery Office. Available at: https://www.nao.org.uk/wp-content/uploads/2014/11/Impact-of-fundingreductions-on-local-authorities.pdf [Accessed: 10/07/2018]

National Federation of Parks and Green Spaces (NFPGS) (2016) A call for effective government action now to save the UK's parks. NFPGS response to the 'Future of Parks' select committee inquiry.

Niemelä, J. (1999) Ecology and urban planning. Biodiversity and Conservation, 8, 1, 119-131. DOI:10.1023/A:1008817325994.

Niemelä, J., Saarela, SR., Söderman, T., Kopperoinen, L., Yli-Pelkonen, V., Väre, S. and Kotze, D. (2010) Using the ecosystem services approach for better planning and conservation of urban green spaces: a Finland case study. Biodiversity and Conservation, 19, 3225-3243. Available at: https://doi.org/10.1007/s10531 010-9888-8

Newcastle City Council (NCC) (2018) The Future of Newcastle's Parks and Allotments. Newcastle upon Tyne: Newcastle City Council. Available at: https://www.newcastle.gov.uk/leisure-libraries-and-tourism/parks-andcountryside/future-newcastles-parks-and-allotments [Accessed: 09/10/2018]

Office for National Statistics (ONS) (2016) Population dynamics of UK city regions since mid-2011. Newport: ONS. Available at: https://www.ons.gov.uk/peoplepopulationandcommunity/populationandmigratio $\underline{\mathrm{n} / \text { populationestimates/articles/populationdynamicsofukcityregionssincemid201 }}$ 1/2016-10-11 [Accessed: 18/03/2018].

Olsen, D. (1993) People's parks: The design and development of Victorian parks in Britain by Hazel Conway [review]. Victorian Studies, 36, 491-492. 
Panduro, T. and Veie, K.L. (2013) Classification and valuation of urban green spaces: a hedonic house price valuation. Landscape and Urban Planning, 120, 119-128. Available at: https://doi.org/10.1016/j.landurbplan.2013.08.009

Peschardta, K., Schipperijnb, J. and Stigsdottera, U. (2012) Use of Small Public Urban Green Spaces (SPUGS). Urban Forestry \& Urban Greening, 11, 3, 235-244. Available at: https://doi.org/10.1016/j.ufug.2012.04.002

Pincetl, S. and Gearin, E. (2005) The reinvention of public green space. Urban Geography, 26, 5, 365-384. Available at: https://doi.org/10.2747/02723638.26.5.365

Platts-Fowler, D. and Robinson, D. (2016) Community resilience: a policy tool for local government?, Local Government Studies, 42, 5, 762-784. DOI: 10.1080/03003930.2016.1186653.

Poulsen, C. (1976) Victoria Park: A Study in the History of East London. London: Stepney Books and the Journeyman Press.

Reeder, D. (2006) London and green space, 1850-2000: an introduction. In P. Clark, ed., The European City and Green Space. Aldershot: Ashgate.

Robson, C. (2011) Real world research: a resource for users of social research methods in applied settings. 3rd edition. Chichester: Wiley.

Rosol, M. (2012) Community volunteering as neoliberal strategy? Green space production in Berlin. Antipode, 44, 1, 239-257. Available at: https://doi:10.1111/j.1467-8330.2011.00861.x

Rutt, R. L. and Gulsrud, N. M. (2016) Green justice in the city: A new agenda for urban green space research in Europe. Urban Forestry \& Urban Greening, 19, 123-127. Available at: https://doi.org/10.1016/j.ufug.2016.07.004

Silverman, D. (ed.) (2004) Qualitative research: theory, method and practice, 2nd edition. London: Sage.

Swanwick, C., Dunnett, N. and Woolley, H. (2003) Nature, role and value of green space in towns and cities: an overview. Built Environment, 29, 2, 94-106. Available at: doi:http://www.jstor.org/stable/23288809.

Talbot, C. and Talbot, C. (2011) Local government strategies in an age of austerity. In: C. Oyarce, (ed.) Redefining Local Government. Public Management and Policy Association. Available at: http://observgo.uquebec.ca/observgo/fichiers/17943_glr1.pdf\#page=73 [Accessed: 25/10/2018]

Taylor, A. W. (1998) Growing Up in the Inner City: Green Spaces as Places to Grow. Environment and Behavior, 30, 1, 3-27. Available at: https://doi.org/10.1177/0013916598301001

Tonkiss, F. (2013) Austerity urbanism and the makeshift city. City, 17:3, 312-324. DOI: 10.1080/13604813.2013.795332.

Turner, T. (1995) Greenways, blueways, skyways and other ways to a better London. Landscape and Urban Planning, 33, (1-3), 269-282. Available at: https://doi.org/10.1016/0169-2046(94)02022-8

Tzoulas, K., Korpela, K., Venn, S., Vli-Pelkonen, V., Kaźmierczak, A., Niemela, J. and James, P. (2007) Promoting ecosystem and human health in urban areas using Green Infrastructure: a literature review. Landscape and Urban Planning, 81, 3, 167-178. Available at: https://doi:10.1016/j.landurbplan.2007.02.001

Urban Parks Forum (2001) Public Park Assessment: A Survey of Local Authority Owned Parks Focusing on Parks of Historic Interest. Caversham: Urban Parks Forum.

Van den Berg, A.E., Hartig, T. and Staats, H. (2007) Preference for nature in urbanized societies: stress, restoration, and the pursuit of sustainability. Journal of Social Issues, 63, 1, 79-96. Available at: https://doi.org/10.1111/j.15404560.2007.00497.x 
Van Herzele, A. and Wiedemann, T. (2003) A monitoring tool for the provision of accessible and attractive urban green spaces. Landscape and Urban Planning, 63, 109-126. Available at: https://doi.org/10.1016/S0169-2046(02)00192-5

Walker, S. and Duffield, B. (1983) Urban parks and open spaces - an overview. Landscape Research, $8, \quad 2, \quad 2-12 . \quad$ Available at: https://doi.org/10.1080/01426398308706060

Whitten, M. (2018) Reconceptualising green space: Planning for urban green space in the contemporary city (thesis). PhD Regional and Urban Planning, London School of Economics.

Wilson, O. and Hughes, O. (2011) Urban green space policy and discourse in England. Planning Practice \& Research, 26, 2, 207-228. Available at: https://doi.org/10.1080/02697459.2011.560462

Woolley, H. (2003) Urban Open Spaces. London: Spoon Press.

Zhang, B. X. (2012) The economic benefits of rainwater-runoff reduction by urban green spaces: A case study in Beijing, China. Journal of Environmental Management, 100, 65-71. Available at: https://doi.org/10.1016/i.jenvman.2012.01.015 